\title{
Treatment with intravenous iloprost in patients with systemic sclerosis: A short review
}

\author{
Elisa Visalli', Giorgio Amato', Marcella Di Gangi', Alessia Benenati' ${ }^{1}$ Nicolò Cino', Caterina Gagliano², Raffaele \\ Falsaperla ${ }^{3}$, Alberto Farina ${ }^{4}$, Rosario Foti ${ }^{*}$ \\ 'Rheumatology Unit, A.O.U. Policlinico Vittorio Emanuele, Catania, Italy \\ ${ }^{2}$ General Pediatrics and Pediatric Acute and Emergeny Unit, A.O.U. Policlinico Vittorio Emanuele, Catania, Italy \\ ${ }^{3}$ Ophthalmology, NEST (Neurovisual Science Technology) and Rare Disease Center (Ra.Di.Ce.), Santa Marta Hospital, Catania, Italy \\ ${ }^{4}$ Medical Affairs Department, Italfarmaco S.p.A., Milano, Italy
}

Article Info

Article Notes

Received: April 29, 2017

Accepted: June 13, 2017

\section{*Correspondence:}

Rosario Foti, Rheumatology Unit, A.O.U. Policlinico Vittorio Emanuele, Catania, Italy; Email: rosfoti@tiscali.it

(C) 2017 Rosario Foti. This article is distributed under the terms of the Creative Commons Attribution 4.0 International License.

\section{Keywords}

Systemic sclerosis

Vasculopathy

Intravenous lloprost

Raynaud's phenomenon

\section{ABSTRACT}

Systemic sclerosis (SSc) is a severe, chronic disease characterised by small vessel vasculopathy, autoantibodies production, and fibroblast dysfunction leading to an excessive deposition of collagen in the skin and internal organs. The beneficial effects of iloprost in improving symptoms of ischemia such as Raynaud's phenomenon (RP) and digital ulcers (DUs) in patients with SSc are largely due to modulating the disordered microcirculation. Literature data show that the long-term IV iloprost administration maintains efficacy in the treatment of vasculopathy, representing a rational therapeutic approach, since Raynaud's phenomenon and digital ulcers are two of the major causes of pain and disability in scleroderma patients. Intravenous iloprost may also play a role in promoting a favourable disease course, as a stabilization of cardio-pulmonary were observed in long-term studies. Current evidences are encouraging, but further randomized and controlled trials are needed to confirm these results.

\section{Introduction}

Scleroderma (systemic sclerosis or SSc) is a severe, chronic disease characterised by small vessel vasculopathy, autoantibodies production, and fibroblast dysfunction leading to an excessive deposition of collagen in the skin and internal organs ${ }^{1,2,3}$. Severe Raynaud's phenomenon (RP) is the early onset symptom in most SSc patients and may precede other clinical manifestations of the disease by many years 4 . The clinical course of the disease often involves the cardiovascular and respiratory systems; the heart can be directly or indirectly involved with the involvement of other organs, especially kidneys and lungs ${ }^{5}$ while for the respiratory system, SSc can affect lung parenchyma and pulmonary blood vessels, leading to interstitial lung disease (ILD) and pulmonary arterial hypertension (PAH). The presence of a cardio-pulmonary involvement generally leads to a poor prognosis for the patient $t^{2}$. Patients with significant internal organ involvement remain often asymptomatic until the late stages of SSc; therefore, routine monitoring for the underlying disease and an intensive medical treatment are essential after the first diagnosis. Despite recent advances in the disease management, SSc remains a treatable but not curable disease ${ }^{2}$.

Current European League Against Rheumatism (EULAR) guidelines recommend Iloprost in the treatment of Raynaud's phenomenon and in the healing of ischemic digital ulcers. In 
particular, intravenous iloprost reduces the frequency and severity of SSc-RP attacks and should be considered for severe SSc-RP and should also be used for the treatment of milder SSc-RP attacks when oral therapy have failed ${ }^{6}$. It should also be considered that treatment with iloprost may offer greater efficacy than calcium antagonists ${ }^{7,8}$. Despite EULAR's recommendations, the correct therapeutic approach is still debated and large differences occur between centres administering such treatment, with implications on clinical practice and health of patients.

\section{Iloprost}

Iloprost is a stable prostacyclin presenting vasodilating, anti-platelet, cytoprotective and immuno-modulating properties, with long-lasting effects at the level of cutaneous microcirculation ${ }^{8,9,10}$. The synthetic prostacyclin analogue iloprost closely mimics the whole range of endogenous prostacyclin's physiological effects (figure 1 ), and is therefore ideally suited for the treatment of micro and macrocirculatory diseases, including disorders in the pulmonary vascular bed, basically determined by an imbalance between prostacyclin with its vasodilatory and anti-platelet effects and thromboxane which acts as a vasoconstrictor and platelet activator. Endogenous prostacyclin assumes a key role in the finely tuned interaction between platelets, leucocytes and endothelium, especially at the level of the microcirculation acting as a vascular repair and protection factor ${ }^{11,12,13}$.
Tissue ischemia beyond the often long standing arterial stenosis or resulting from vasospastic attacks, may be barely adequate to support nutrition in normal circumstances but when intercurrent infection or minor injury is superimposed, the microcirculation breaks down leading to pain, ulceration or gangrene. The low perfusion pressure and decreased microcirculatory blood flow precipitate cellular and biochemical changes, which however can be reversible. The typical changes in severely ischemic areas are an uneven distribution of the nutritive capillary blood flow associated with capillary plugging. The key players are the platelets, white cells and the endothelium. It has been suggested that the low perfusion pressure in the severely ischemic microcirculation causes unbalanced activation of these components. The endothelial damage/disturbance promotes vasoconstriction via release of endotheliumderived constricting factor, endothelin, thromboxane A2, and serotonin, leukocyte adhesion, platelet adhesion and subsequent release of e.g. mitogens, and impairment of the fibrinolytic balance with inappropriate release of tissuetype plasminogen activator and its plasminogen activator inhibitor. Inflammatory factors are involved in these processes to a varying extent (Figure 2).

The overall effect is to cause occlusion of much of the microcirculation by platelet, white cell, fibrin or thrombotic plugs. Disordered vasomotion increases further the maldistribution of blood flow in the microcirculation. Correction of this imbalance is the

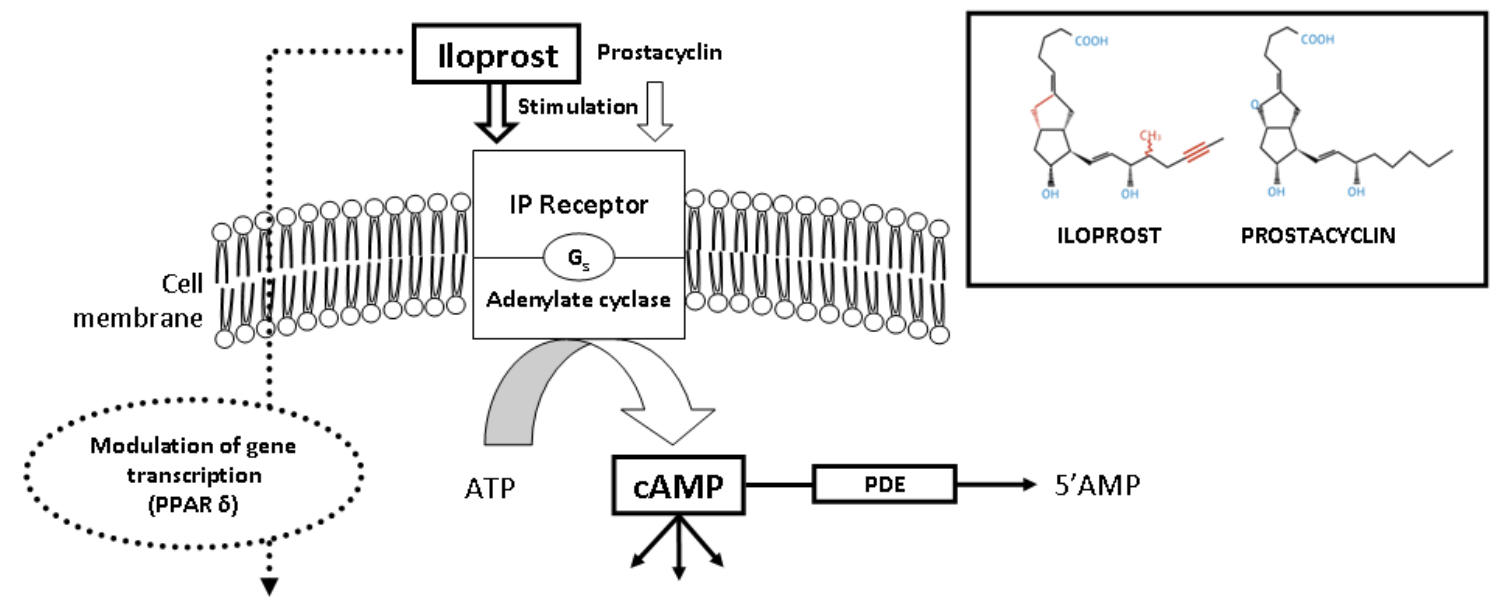

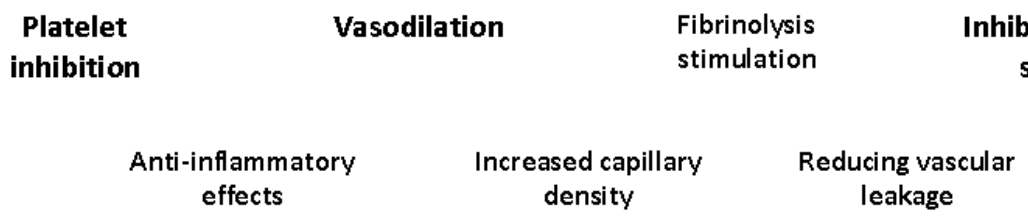

Figure 1: Mode of action of iloprost

ATP: Adenosine triphosphate; AMP: adenosine monophosphate; cAMP: Cyclic adenosine monophosphate; PDE: Phosphodiesterase; PPAR: peroxisome proliferator-activated receptor. 


\section{ALTERED MICROCIRCULATION: IMPAIRED AND IRREGULAR PERFUSION}

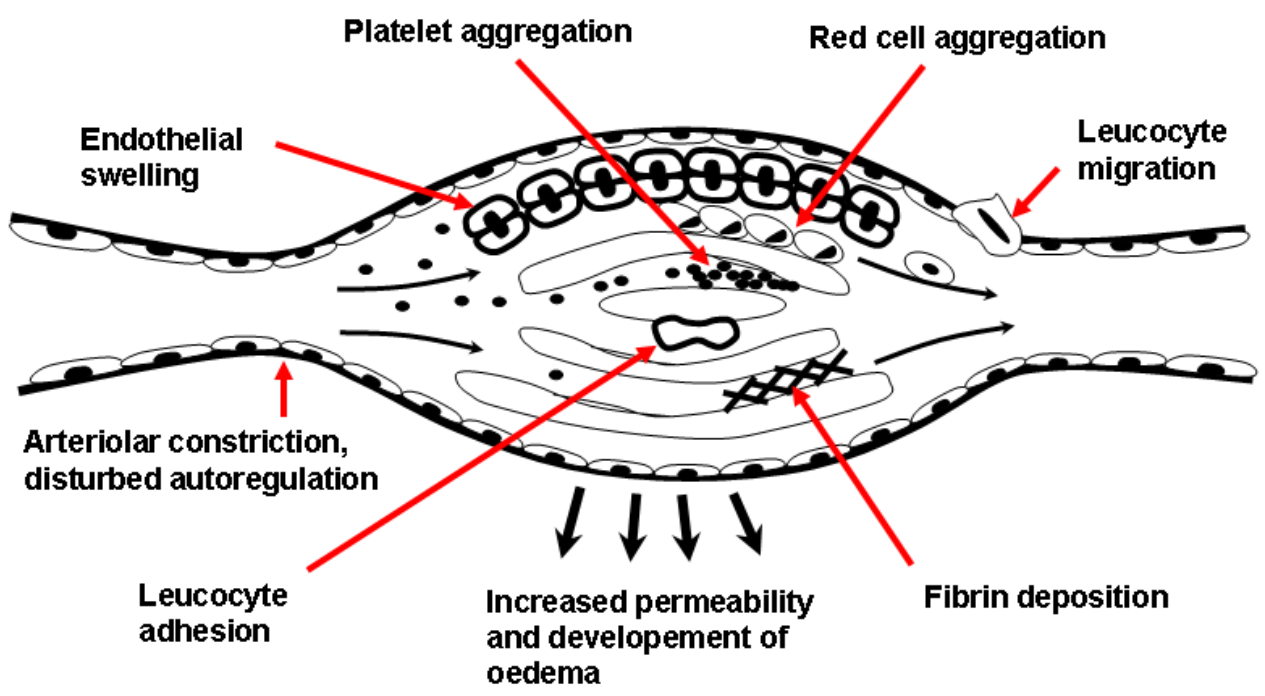

Figure 2

\section{RESTORED MICROCIRCULATION: IMPROVED PERFUSION}

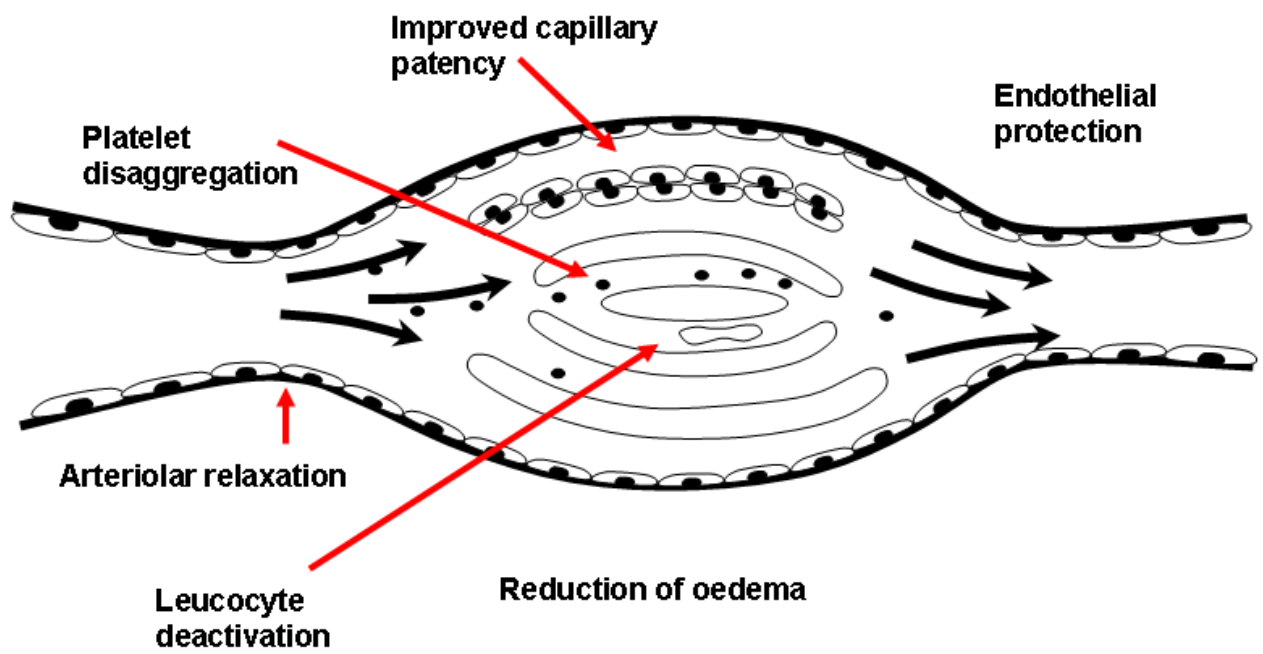

Figure 3

therapeutic approach for the administration of iloprost. The beneficial effects of iloprost in improving symptoms of ischemia such as Raynaud's phenomenon and digital ulcers in patients with SSc are largely due to modulating the disordered microcirculation. Iloprost restores the disturbed microcirculation by inducing vasodilatation, inhibiting platelet activation, repairing and protecting the endothelium, activating the endogenous fibrinolysis and by correcting cytokine network imbalances (Figure 3). The effects of iloprost are mediated by its binding to specific 
prostaglandin I2 (PGI2) receptors and by a subsequent increase in cellular cyclic adenosine monophosphate (cAMP). More recently described, also peroxisome proliferator-activated receptor delta (PPAR $\delta$ ) activation plays a role in controlling the cell fate, i.e. apoptosis ${ }^{14,15}$.

\section{Clinical data on the use of iloprost in SSc}

Clinical data from the literature show an improvement in the frequency, duration and intensity of ischemic episodes for up to at least 6 weeks after a short (3 to 5 days) course of intravenous iloprost. Improved healing of active digital ulcers was also reported. Table 1 summarizes the main studies reported in the literature on the use of iloprost in patients with SSc. The long-term studies show the maintenance of efficacy on the vascular symptoms over time. This is an important therapeutic goal since iloprost administration aims to correct vasculopathy and restore the function of microcirculation, which are key factors in the disease. Long-term treatment of vasculopathy may therefore represent a rational therapeutic approach: it has an impact on the quality of patient's life - since RP and DUs are two of the major causes of pain and disability in these patients - and may potentially have a favorable impact on the evolution of the disease. In fact, a low incidence of severe vascular complications, such as pulmonary arterial hypertension, or a stabilization of cardiopulmonary parameters was observed in long-term studies ${ }^{7,825,26}$.

Recently, at the Rheumatology Unit of Policlinico Vittorio Emanuele, Catania, Italy, the disease progression, specifically in terms of cardiopulmonary function, was

Table 1. Summary of the main clinical studies

\begin{tabular}{|c|c|c|c|c|c|c|c|c|}
\hline Study & Design & Patients & $\begin{array}{c}\text { Infusion } \\
\text { length }\end{array}$ & Rate & $\begin{array}{l}\text { Treatment } \\
\text { start }\end{array}$ & $\begin{array}{l}\text { Treatment } \\
\text { repetition }\end{array}$ & Main outcome & $\begin{array}{l}\text { Follow- } \\
\text { up }\end{array}$ \\
\hline $\begin{array}{l}\text { Yardumian, } \\
1988^{16}\end{array}$ & RCT & 12 & $5 \mathrm{~h}$ & $\begin{array}{l}1.0-3.0 \\
\mathrm{ng} / \mathrm{kg} / \mathrm{min}\end{array}$ & 3 days & - & $\begin{array}{l}\text { Improvement of RP symptomatology } \\
\text { Digital and nail bed flow increased }\end{array}$ & 6 weeks \\
\hline $\begin{array}{l}\text { McHugh, } \\
1988^{17}\end{array}$ & $\mathrm{RCT}$ & 29 & $3-6 h$ & $\begin{array}{l}0.5-2.0 \\
\mathrm{ng} / \mathrm{kg} / \mathrm{min}\end{array}$ & 3 days & - & $\begin{array}{l}\text { Reduction in number and severity of RP- } \\
\text { attacks compared with placebo; }\end{array}$ & 6 weeks \\
\hline $\begin{array}{l}\text { Rademaker, } \\
1989^{7}\end{array}$ & RCT & 23 & $8 \mathrm{~h}$ & $\begin{array}{l}0.5-2.0 \\
\mathrm{ng} / \mathrm{kg} / \mathrm{min}\end{array}$ & 3 days & $\begin{array}{l}1 \text { day / } 8 \\
\text { weeks }\end{array}$ & $\begin{array}{l}\text { Reduction in the number, duration and } \\
\text { severity of attacks of RP; } \\
\text { Reduction in mean number of DUs; } \\
\text { increase in hand temperature and digital and } \\
\text { microcirculatory blood flow }\end{array}$ & 4 months \\
\hline $\begin{array}{l}\text { Constans, } \\
1991^{18}\end{array}$ & $\mathrm{RCT}$ & 12 & $6 \mathrm{~h}$ & $\begin{array}{l}0.5-2.0 \\
\mathrm{ng} / \mathrm{kg} / \mathrm{min}\end{array}$ & $11 \pm 7$ days & - & $\begin{array}{l}\text { No substantial increase in Transcutaneous } \\
\text { pO2; } \\
\text { Clinical improvement }\end{array}$ & $11 \pm 7$ days \\
\hline Torley, $1991^{19}$ & RCT & 55 & $6 \mathrm{~h}$ & $\begin{array}{l}0.5 \text { or } 2.0 \\
\mathrm{ng} / \mathrm{kg} / \mathrm{min}\end{array}$ & 3 days & - & $\begin{array}{l}\text { Reduction in frequency, } \\
\text { duration, and severity of attacks of RP, } \\
\text { Ulcer healing in } 44 \% \text { (High dose) and } 39 \% \text { (Low } \\
\text { dose) of patients }\end{array}$ & 8 weeks \\
\hline Kyle, $1992^{20}$ & RCT & 13 & $6 \mathrm{~h}$ & $\begin{array}{l}0.5-2.0 \\
\mathrm{ng} / \mathrm{kg} / \mathrm{min}\end{array}$ & 3 days & - & Reduction in frequency of Raynaud's attacks & 6 weeks \\
\hline $\begin{array}{l}\text { Wigley, } \\
1992^{21}\end{array}$ & $\mathrm{RCT}$ & 35 & $6 \mathrm{~h}$ & $\begin{array}{l}0.5-2.0 \\
\mathrm{ng} / \mathrm{kg} / \mathrm{min}\end{array}$ & 5 days & - & $\begin{array}{l}\text { Complete healing of cutaneous lesions; } \\
\text { Reduction of the number, duration and } \\
\text { severity of attacks of PR; } \\
\text { Decrease in critical ischemic temperature; } \\
\text { Improvement in the rate of skin temperature } \\
\text { recovery following cold challenge }\end{array}$ & 10 weeks \\
\hline $\begin{array}{l}\text { Wigley, } \\
1994^{22}\end{array}$ & RCT & 131 & $6 \mathrm{~h}$ & $\begin{array}{l}0.5-2.0 \\
\mathrm{ng} / \mathrm{kg} / \mathrm{min}\end{array}$ & 5 days & - & $\begin{array}{l}\text { Reduction of mean number of RP attacks; } \\
\text { improvement in a global Raynaud severity } \\
\text { score; } \\
\text { Effective in healing of cutaneous lesions }\end{array}$ & 9 weeks \\
\hline $\begin{array}{l}\text { Zachariae, } \\
1996^{23}\end{array}$ & 0 & 12 & $6 \mathrm{~h}$ & $\begin{array}{l}0.5-2.0 \\
\mathrm{ng} / \mathrm{kg} / \mathrm{min}\end{array}$ & 8-13 days & - & $\begin{array}{l}2 \text { patients with RP noted a temporary } \\
\text { improvement lasting several weeks; } \\
\text { Imminent gangrene was arrested and followed } \\
\text { by total healing; } \\
\text { All ischemic ulcers healed in } 4 \text { of } 6 \text { patients, } \\
\text { while the remaining } 2 \text { patients experienced } \\
\text { partial healing. }\end{array}$ & 13 days \\
\hline
\end{tabular}


Visalli E, Amato G, Gangi MD, Benenati A, Cino N, Gagliano C, Falsaperla R, Farina A, Foti R. Journal of Rare Diseases Research \& Treatment J Rare Dis Res Treat. (2017) 2(4): 6-13

\begin{tabular}{|c|c|c|c|c|c|c|c|c|}
\hline Biasi, $1998^{24}$ & $\mathrm{O}$ & 20 & $6 \mathrm{~h}$ & $\begin{array}{l}0.5-2.0 \\
\mathrm{ng} / \mathrm{kg} / \mathrm{min}\end{array}$ & - & $\begin{array}{l}5 \text { days / } 3 \\
\text { Months }\end{array}$ & $\begin{array}{l}\text { Decrease in scleroderma skin lesion score; } \\
\text { Ischemic lesion improvement } \\
\text { No difference in VAS and DLCO }\end{array}$ & 1 year \\
\hline Filaci, $1999^{25}$ & $\mathrm{RCT}$ & 20 & $6 \mathrm{~h}$ & $\begin{array}{l}1.0 \\
\mathrm{ng} / \mathrm{kg} / \mathrm{min}\end{array}$ & - & $\begin{array}{l}5 \text { days / } \\
\text { Month }\end{array}$ & $\begin{array}{l}\text { Improvement of skin, microvascular and } \\
\text { esophageal morphological and functional } \\
\text { parameters; } \\
\text { Reduction of IL-6 serum concentration }\end{array}$ & 1 year \\
\hline Scorza, $2001^{8}$ & RCT & 46 & $8 \mathrm{~h}$ & $\begin{array}{l}0.5-2.0 \\
\mathrm{ng} / \mathrm{kg} / \mathrm{min}\end{array}$ & 5 days & $\begin{array}{l}1 \text { day / } 6 \\
\text { weeks }\end{array}$ & $\begin{array}{l}\text { Reduction of skin score; } \\
\text { DLCO remained stable }\end{array}$ & 1 year \\
\hline $\begin{array}{l}\text { Bettoni, } \\
2002^{26}\end{array}$ & 0 & 30 & $6 \mathrm{~h}$ & $\begin{array}{l}0.5-2.0 \\
\mathrm{ng} / \mathrm{kg} / \mathrm{min}\end{array}$ & 5 days & $\begin{array}{c}1 \text { day / } 3 \\
\text { weeks }\end{array}$ & $\begin{array}{l}\text { Complete healing of digital ulcers in } 90 \% \text { of } \\
\text { patients; } \\
\text { Decrease of the RP-VAS and of Rodnan skin } \\
\text { thickness score; } \\
\text { DLCO/VA decreased from } 71 \% \text { to } 62 \%\end{array}$ & 3 years \\
\hline Milio, $2006^{27}$ & RCT & 60 & $6 \mathrm{~h}$ & $\begin{array}{l}0.5-2.0 \\
\mathrm{ng} / \mathrm{kg} / \mathrm{min}\end{array}$ & - & $\begin{array}{l}\text { Group A: } \\
10 \text { days / } 3 \\
\text { months } \\
\text { Group B1: } \\
1 \text { day / } \\
\text { month } \\
\text { Group B: } \\
20 \text { days / } 6 \\
\text { months }\end{array}$ & $\begin{array}{l}\text { Reduction in the number, duration and } \\
\text { severity of attacks of RP; } \\
\text { Improvement of Quality of Life }\end{array}$ & $\begin{array}{c}18 \\
\text { months }\end{array}$ \\
\hline $\begin{array}{l}\text { Caramaschi, } \\
2006^{28}\end{array}$ & $\mathrm{O}$ & 81 & $6 \mathrm{~h}$ & $\begin{array}{l}0.5-2.0 \\
\mathrm{ng} / \mathrm{kg} / \mathrm{min}\end{array}$ & - & $\begin{array}{l}1 \text { day / } \\
\text { Month, or } \\
5 \text { days / } 3 \\
\text { Months }\end{array}$ & $\begin{array}{l}\text { None of patients developed severe isolated } \\
\text { pulmonary hypertension; } \\
\text { None of patients developed scleroderma renal } \\
\text { crisis. }\end{array}$ & $1-3$ years \\
\hline $\begin{array}{l}\text { Balbir } \\
\text { Gurman, } \\
2007^{29}\end{array}$ & $\mathrm{O}$ & 12 & $8 \mathrm{~h}$ & $\begin{array}{l}0.5-2.0 \\
\mathrm{ng} / \mathrm{kg} / \mathrm{min}\end{array}$ & 5 days & - & $\begin{array}{l}\text { Reduction of malondialdehyde levels } \\
\text { Increase in Catalase and Superoxide dismutase } \\
\text { levels }\end{array}$ & 5 days \\
\hline Airò, $2007^{30}$ & $\mathrm{O}$ & 112 & $6 \mathrm{~h}$ & $\begin{array}{l}0.5-2.0 \\
\mathrm{ng} / \mathrm{kg} / \mathrm{min}\end{array}$ & 5 days & $\begin{array}{c}1 \text { day / } 3 \\
\text { weeks }\end{array}$ & $\begin{array}{l}\text { Decrease in the Raynaud's phenomenon } \\
\text { VAS and Rodnan skin thickness score } \\
\text { compared to the pre-treatment point; } \\
\text { No significant difference with regard to } \\
\text { changes in lung function tests over time } \\
\text { compared with a control group; }\end{array}$ & 4 years \\
\hline Scarsi, $2008^{31}$ & 0 & 59 & $6 \mathrm{~h}$ & $\begin{array}{l}0.5-2.0 \\
\mathrm{ng} / \mathrm{kg} / \mathrm{min}\end{array}$ & 5 days & $\begin{array}{c}1 \text { day / } 3 \\
\text { weeks }\end{array}$ & $\begin{array}{l}\text { Improvement of RP symptomatology } \\
\text { Reduction in mean number of DUs; } \\
\text { Decrease of the modified Rodnan Skin } \\
\text { thickness score }\end{array}$ & 4 years \\
\hline $\begin{array}{l}\text { Kawald, } \\
2008^{32}\end{array}$ & RCT & 50 & $6 \mathrm{~h}$ & $\begin{array}{l}0.5-2.0 \\
\mathrm{ng} / \mathrm{kg} / \mathrm{min}\end{array}$ & 21 days & $\begin{array}{l}21 \text { days } \\
\text { once or } \\
\text { twice a } \\
\text { year }\end{array}$ & $\begin{array}{l}\text { Reduction in the number, duration and } \\
\text { severity of attacks of RP; } \\
\text { DLCO and FVC remained stable }\end{array}$ & 2 years \\
\hline $\begin{array}{l}\text { Caramaschi, } \\
2009^{33}\end{array}$ & 0 & 85 & $6 \mathrm{~h}$ & $\begin{array}{l}0.5-2.0 \\
\mathrm{ng} / \mathrm{kg} / \mathrm{min}\end{array}$ & - & $\begin{array}{l}1 \text { day / } \\
\text { Month, or } \\
5 \text { days / } 3 \\
\text { Months }\end{array}$ & $\begin{array}{l}\text { Delay in beginning iloprost therapy ( }>18 \\
\text { months from the SSc onset) is a potential } \\
\text { modifiable risk factor associated with ischemic } \\
\text { DUs OR= } 5.70(95 \% \mathrm{Cl} 1.96-16.59)\end{array}$ & 7 years \\
\hline Bali, $2011^{34}$ & RCT & 17 & $3 \mathrm{~h}$ & $\begin{array}{l}0.5-2.0 \\
\mathrm{ng} / \mathrm{kg} / \mathrm{min}\end{array}$ & 5 days & $\begin{array}{l}5 \text { days / } \\
\text { Month }\end{array}$ & $\begin{array}{l}\text { No significant reduction in the number, } \\
\text { duration and severity of attacks of RP }\end{array}$ & 4 months \\
\hline $\begin{array}{l}\text { Caravita, } \\
2011^{35}\end{array}$ & $\mathrm{O}$ & 14 & $6 \mathrm{~h}$ & $\begin{array}{l}0.5-2.0 \\
\mathrm{ng} / \mathrm{kg} / \mathrm{min}\end{array}$ & - & $\begin{array}{l}5 \text { days / } 6 \\
\text { weeks }\end{array}$ & $\begin{array}{l}\text { Pulmonary Arterial Systolic Pressure (PASP) } \\
\text { significantly decreased; } \\
6 \text { Minute-Walk Distance (6MWD) increased; } \\
\text { PASP resulted significantly correlated with } \\
\text { N-terminal pro b-type natriuretic peptide (NT- } \\
\text { proBNP) }\end{array}$ & 8 months \\
\hline
\end{tabular}




\begin{tabular}{|c|c|c|c|c|c|c|c|c|}
\hline $\begin{array}{l}\text { Casigliani } \\
\text { Rabl,I } 2012^{36}\end{array}$ & $\mathrm{O}$ & 73 & - & $\begin{array}{l}1.0-1.5 \\
\mathrm{ng} / \mathrm{kg} / \mathrm{min}\end{array}$ & - & $\begin{array}{l}1 \text { day / } 3 \\
\text { Months }\end{array}$ & $\begin{array}{l}\text { Complete healing of DU in } 25 / 28 \text { patients; } \\
\text { Improvement of RP symptomatology }\end{array}$ & $1-8$ years \\
\hline $\begin{array}{l}\text { Caramaschi, } \\
2012^{37}\end{array}$ & 0 & 115 & $6 \mathrm{~h}$ & $\begin{array}{l}0.5-2.0 \\
\mathrm{ng} / \mathrm{kg} / \mathrm{min}\end{array}$ & - & $\begin{array}{l}1 \text { day / } \\
\text { Month, or } \\
5 \text { days / } 3 \\
\text { Months }\end{array}$ & $\begin{array}{l}\text { Low incidence of digital gangrene requiring } \\
\text { amputation; }\end{array}$ & 8 years \\
\hline $\begin{array}{l}\text { Auriemma, } \\
2013^{38}\end{array}$ & 0 & 28 & $3 \mathrm{~h}$ & $\begin{array}{l}0.5-2.0 \\
\mathrm{ng} / \mathrm{kg} / \mathrm{min}\end{array}$ & 1-3 days & $\begin{array}{l}1-3 \text { days / } \\
3 \text { Months }\end{array}$ & $\begin{array}{l}\text { Improvement of RP symptomatology; } \\
\text { IL-23 modulation }\end{array}$ & $\begin{array}{l}12-16 \\
\text { weeks }\end{array}$ \\
\hline $\begin{array}{l}\text { De Cata, } \\
2016^{39}\end{array}$ & 0 & 34 & $6 \mathrm{~h}$ & $\begin{array}{l}0.5-2.0 \\
\mathrm{ng} / \mathrm{kg} / \mathrm{min}\end{array}$ & 1 day & $\begin{array}{l}1 \text { day / } \\
\text { Month }\end{array}$ & $\begin{array}{l}\text { Complete healing of DUs in } 49,3 \% \text { of patients; } \\
\text { Partial healing of DUs in } 26,1 \% \text { of patients; } \\
24,6 \% \text { did not respond }\end{array}$ & 6 months \\
\hline $\begin{array}{l}\text { Trombetta, } \\
2016^{40}\end{array}$ & 0 & 30 & $24 \mathrm{~h}$ & $\begin{array}{l}0.5-2.0 \\
\mathrm{ng} / \mathrm{kg} / \mathrm{min}\end{array}$ & - & $\begin{array}{l}5 \text { days / } 3 \\
\text { Months }\end{array}$ & $\begin{array}{l}\text { lloprost + bosentan } \\
\text { Increase in fingertip blood perfusion and in } \\
\text { absolute nail fold capillary number } / \mathrm{mm} \\
\text { Reduction }(80 \%) \text { in the incidence of new DU. } \\
\text { DLCO and SPAP did not worsen }\end{array}$ & 4 years \\
\hline $\begin{array}{l}\text { Colaci, } \\
2016^{41}\end{array}$ & 0 & 50 & $6 \mathrm{~h}$ & $\begin{array}{l}0.8-1.0 \\
\mathrm{ng} / \mathrm{kg} / \mathrm{min}\end{array}$ & - & $\begin{array}{l}\text { 1-3 days / } \\
\text { Month }\end{array}$ & $\begin{array}{l}\text { Reduction in mean number of DUs; } \\
71 \% \text { of DUs improved during the follow-up }\end{array}$ & 10 years \\
\hline Foti, $2016^{42}$ & $\mathrm{O}$ & 68 & $6 \mathrm{~h}$ & $\begin{array}{l}0.5-2.0 \\
\mathrm{ng} / \mathrm{kg} / \mathrm{min}\end{array}$ & - & $\begin{array}{l}\text { 5-6 days / } \\
\text { Month }\end{array}$ & $\begin{array}{l}\text { Reduction in the occurrence of DUs; } \\
\text { None of the free-DUs patients at baseline } \\
\text { presented DUs at the end of follow-up; } \\
\text { Improvement in tricuspid annular plane } \\
\text { systolic excursion, SPAP, and brain natriuretic } \\
\text { peptide. }\end{array}$ & 7 years \\
\hline $\begin{array}{l}\text { Cestelli, } \\
2017^{43}\end{array}$ & 0 & 95 & - & $\begin{array}{l}2.0 \mathrm{ng} / \mathrm{kg} / \\
\min \end{array}$ & 1 month & $\begin{array}{l}1 \text { day / } \\
\text { Month }\end{array}$ & $\begin{array}{l}\text { Reduction of the number of giant capillaries; } \\
\text { increase of ramified capillaries in iloprost + } \\
\text { bosentan group }\end{array}$ & 1 year \\
\hline
\end{tabular}

Abbreviations: RCT: randomized clinical trial, O: observational study, SSc: systemic sclerosis, RP: Raynaud's phenomenon, DUs: digital ulcers, VAS: visual analogue scale, DLCO: diffusing capacity of the lung for carbon monoxide, VA: alveolar volume, FVC: forced vital capacity, OR: odds ratio, sPAP: systolic pulmonary artery pressure.

evaluated in a group of 68 consecutive SSc patients treated with iloprost with a schedule of 5-6 consecutive daily infusions per month (6 h/day, 0.5-2.0 ng/ $\mathrm{kg} / \mathrm{min})$, during a 7 years follow-up ${ }^{41}$.

Data show a stabilization of the cardiopulmonary disease, in particular in a very long-term follow-up and this results are first supported by NYHA class non-progression and a significant reduction of systolic pulmonary arterial pressure (sPAP), brain natriuretic peptide levels (BNP) and improvement of tricuspid annular plane systolic excursion (TAPSE) values in study population. In particular, a significant sPAP reduction was observed in the subgroup of patients with baseline sPAP $\geq 36 \mathrm{mmHg}$ and after an average long-term follow-up. The EUSTAR working group recently showed the importance of SPAP considering that baseline values $\geq 36 \mathrm{mmHg}$ were significantly associated with an increased risk of death up to 3-year follow-up ${ }^{44}$ while BNP levels is an important diagnostic marker of early pulmonary artery hypertension and TAPSE is important for assessing disease severity, stability, and prognosis in $\mathrm{PAH}$ patients, with a cut-off value $>20 \mathrm{~mm}$ indicating a satisfactory patient status ${ }^{45,46}$. It was also observed a stabilization of interstitial lung disease markers, such as Diffusing capacity of the Lung for Carbon Monoxide (DLCO), Forced Vital Capacity (FVC), Alveolar Volume (VA), and DLCO/VA and favourable effect on skin involvement with a significant change of Rodnan skin score value. Finally, the long-term effectiveness of the therapy was confirmed since a significant reduction in the prevalence of digital ulcers was observed.

Concerning the safety profile, data from the literature show a satisfactory tolerability of the drug both in the short and long-term studies, the most common side effects, mainly due to the vasodilating properties of the drug, can be managed with the optimal titration of the individual dose at beginning of treatment.

\section{Conclusions}

SSc remains a disease characterized by a poor prognosis due to the occurrence of cardiopulmonary complications and the long-term disease stabilization represents an important therapeutic goal. Intravenous iloprost acts on small vessel vasculopathy, which is one of the key factors of the disease, with proven effectiveness in the treatment 
of Raynaud's phenomenon and digital ulcers. Data from observational studies suggest that an intensive and chronic regimen of IV iloprost administration may lead to the stabilization of disease in SSc patients but randomized and controlled trials are needed to confirm these promising results.

\section{Conflict of Interest}

Alberto Farina is an employee of Italfarmaco S.p.A., the other authors report no conflict of interest.

\section{References}

1. Gabrielli A, Avvedimento EV, Krieg T. Scleroderma. N Engl J Med. 2009; 360(19): 1989-2003.

2. Hinchcliff M, Varga J. Systemic sclerosis/scleroderma: a treatable multisystem disease. Am Fam Physician. 2008; 78(8): 961-968.

3. O'Reilly S, Hügle T, van Laar JM, et al. T cells in systemic sclerosis: A reappraisal. Rheumatology Oxford. 2012; 51: 1540-1549

4. Herrick AL. Vascular function in systemic sclerosis. Curr Opin Rheumatol. 2000; 12: 527-533.

5. Champion HC. The heart in scleroderma. Rheum Dis Clin North Am 2008; 34(1): 181-190.

6. Kowal-Bielecka 0, Franzen J, Avouac J, et al. Update of EULAR recommendations for the treatment of systemic sclerosis. Ann Rheum Dis. 2016; 0: 1-13.

7. Rademaker M, Cooke ED, Almond NE, et al. Comparison of intravenous infusions of iloprost and oral nifedipine in treatment of Raynaud's phenomenon in patients with systemic sclerosis: a double blind randomised study. Br Med J. 1989; 298: 561-564.

8. Scorza R, Caronni M, Mascagni B, et al. Effects of long-term cyclic iloprost therapy in systemic sclerosis with Raynaud's phenomenon. A randomized, controlled study. Clin Exp Rheumatol. 2001; 19: 503508 .

9. Della Bella S, Molteni M, Compasso S, et al. Differential effects of cyclo-oxygenase pathway metabolites on cytokine production by $\mathrm{T}$ lymphocytes. Prostaglandins Leukot Essent Fatty Acids. 1997; 56 177-184.

10. Grant SM, Goa KL. Iloprost. A review of its pharmacodynamic and pharmacokinetic properties, and therapeutic potential in periphera vascular disease myocardial ischaemia and extracorporeal circulation procedures. Drugs. 1992; 43(6): 889-924.

11. Lowe G. Pathophysiology of Critical Leg Ischaemia. Critical Leg Ischaemia - its Pathophysiology and Management. 1990: 17-38.

12. Norden C, Heine H. Arteriosklerose und Thrombose. Dtsch Arztebl. 1988; 85(39): A-2692.

13. Thiemermann C. Biosynthesis and interaction of endothelium-derived vasoactive mediators. Eicosanoids. 1991; 4(4): 187-202.

14. Kawabe J, Ushikubi F, Hasabe N. Prostacyclin in Vascular DiseasesRecent Insights and Future Perspectives. Circ J. 2010; 74(5): 836 843.

15. Hatae T, Wada M, Yokoyama C, et al. Prostacyclin-dependent Apoptosis Mediated by PPARס. J Biol Chem. 2001; 276(49): 46260-46267.

16. Yardumian DA, Isenberg DA, Rustin M, et al. Successful treatment of Raynaud's Syndrome with Iloprost, a chemically stable prostacyclin analogue. Br J Rheumatol. 1988; 27: 220-226.

17. McHugh NJ, Csuka M, Watson $\mathrm{H}$, et al. Infusion of Iloprost, prostacyclin analogue, for treatment of Raynaud's phenomenon in systemic sclerosis. Ann Rheum Dis. 1988; 47(1): 43-47.
18. Constans T, Diot E, Lasfargues G. Iloprost for scleroderma. Ann Intern Med. 1991; 114(7): 606.

19. Torley HI, Madhok R, Capell HA et al. A double blind, randomised, multicenter comparison of two doses of intravenous iloprost in the treatment of Raynaud's phenomenon secondary to connective tissue diseases. Ann Rheum Dis. 1991; 50: 800-804.

20. Kyle MV, Belcher G, Hazelman BL. Placebo controlled study showing therapeutic benefit of iloprost in the treatment of Raynaud's Phenomenon. J Rheumatol. 1992; 19: 1403-1406.

21. Wigley FM, Seibold JR, Wise RA, et al. Intravenous iloprost treatment of Raynaud's Phenomenon and ischemic ulcers secondary to Systemic Sclerosis. J Rheumatol. 1992; 19(9): 1407-14.

22. Wigley FM, Wise RA, Seibold JR, et al. Intravenous iloprost infusion in patients with Raynaud phenomenon secondary to systemic sclerosis a multicenter placebo-controlled double-blind study. Ann Intern Med. 1994; 120(3): 199-206.

23. Zachariae $\mathrm{H}$, Halkier-Sørensen L, Bjerring P, et al. Treatment of ischaemic digital ulcers and prevention of gangrene with intravenous iloprost in systemic sclerosis. Acta Derm Venereol. 1996; 76(3): 236238.

24. Biasi D, A Carletto, P Caramaschi, et al. Iloprost as cyclic five-day infusions in the treatment of scleroderma. An open pilot study in 20 patients treated for one year. Rev Rhum Engl Ed. 1998; 65: 745-750.

25. Filaci G, Cutolo M, Scudeletti M, et al. Cyclosporin A and iloprost treatment of systemic sclerosis: clinical results and interleukin-6 serum changes after 12 months of therapy. Rheumatology. 1999; 38: 992-996.

26. Bettoni L, Geri A, Airò P, et al. Systemic Sclerosis Therapy with Iloprost: A Prospective Observational Study of 30 Patients Treated for a Median of 3 Years. Clin Rheumatol. 2002; 21: 244-250.

27. Milio G, Corrado E, Genova C, et al. Iloprost treatment in patients with Raynaud's phenomenon secondary to systemic sclerosis and the quality of life: a new therapeutic protocol. Rheumatology Oxford. 2006; 45(8): 999-1004.

28. Caramaschi P, Volpe A, Tinazzi I, et al. Does cyclically iloprost infusion prevent severe isolated pulmonary hypertension in systemic sclerosis? Preliminary results. Rheumatol Int. 2006; 27(2): 203-205.

29. Balbir Gurman A, Braun Moscovici Y, Livshitz V, et al. Antioxidant status after iloprost treatment in patients with Raynaud's phenomenon secondary to systemic sclerosis. Clin Rheumatol. 2007; 26: 15171521.

30. Airò P, Rossi M, Scarsi M, et al. Disease-modifying effects of long-term cyclic iloprost therapy in systemic sclerosis. A retrospective analysis and comparison with a control group. Clin Exp Rheumatol. 2007; 25: 722-727

31. Scarsi M, Rossi M, Danieli E, et al. Effetti a lungo termine della terapia ciclica con iloprost nella sclerosi sistemica. Reumatismo. 2008; 60(2): 114-119.

32. Kawald A, Burmester GR, Huscher D, et al. Low versus High-dose Iloprost therapy over 21 days in patients with Secondary Raynaud's Phenomenon and Systemic Sclerosis a randomized open single-center study. J Rheumatol. 2008; 35: 1830-1837.

33. Caramaschi P, Martinelli M, Volpe A, et al. A score of risk factors associated with ischemic digital ulcers in patients affected by systemic sclerosis treated with iloprost. Clin Rheumatol. 2009; 28(7): 807-813.

34. Bali G, Schwantzer G, Aberer F, et al. Discontinuing long-term Iloprost treatment for Raynaud's Phenomenon and systemic sclerosis a singlecenter randomized placebo-controlled double-blind study. Acta Dermatovenerol Alp Pannonica Adriat. 2011; 20(1): 13-21. 
35. Caravita S, Wu SC, Secchi MB, et al. Long-term effects of intermittent Iloprost infusion on pulmonary arterial pressure in connective tissue disease. Eur J Intern Med. 2011; 22: 518-521.

36. Casigliani Rabl S, Della Rossa A, Pepe P, et al. Long-term cyclic intravenous iloprost in systemic sclerosis: clinical experience from a single center. Reumatismo. 2012; 64(3): 158-165.

37. Caramaschi P, Dalla Grassa A, Prati D, et al. Severe vascular complications in patients affected by systemic sclerosis cyclically treated with iloprost. Rheumatol Int. 2012; 32: 1933-1938.

38. Auriemma M, Vianale G, Reale $M$, et al. Iloprost treatment summersuspension effects on skin thermal properties and cytokine profile in systemic sclerosis patients. G Ital Dermatol Venereol. 2013; 148(2): 209-216.

39. De Cata A, Inglese M, Molinaro F, et al. Digital ulcers in scleroderma patients: A retrospective observational study. Int J Immunopathol Pharmacol. 2016; 29(2): 180-187.

40. Trombetta AC, Pizzorni C, Ruaro B, et al. Effects of Longterm Treatment with Bosentan and Iloprost on Nailfold Absolute Capillary Number Fingertip Blood Perfusion and Clinical Status in Systemic Sclerosis. J Rheumatol. 2016; 43(11): 2033-2041.

41. Colaci M, Lumetti F, Giuggioli D, et al. Treatment of sclerodermarelated digital ulcers with iloprost a cohort study. Rheum Dis. 2016 75(2): 1117
42. Foti R, Visalli E, Amato G, et al. Long-term clinical stabilization of scleroderma patients treated with a chronic and intensive IV iloprost regimen. Rheumatol Int. 2017; 37(2): 245-249.

43. Cestelli V, Manfredi A, Sebastiani M, et al. Effect of treatment with iloprost with or without bosentan on nailfold videocapillaroscopic alterations in patients with systemic sclerosis. Mod Rheumatol. 2017; 27(1): 110-114.

44. Hachulla E, Clerson P, Airò P, et al. Value of systolic pulmonary arterial pressure as a prognostic factor of death in the systemic sclerosis EUSTAR population. Rheumatology. 2015; 54(7): 1262-1269.

45. Allanore Y, Borderie D, Meune C, et al. N-terminal pro-brain natriuretic peptide as a diagnostic marker of early pulmonary artery hypertension in patients with systemic sclerosis and effects of calcium-channel blockers. Arthritis Rheum. 2003; 48(12): 3503-3508.

46. Galiè N, Hoeper MM, Humbert M, et al. ESC Committee for Practice Guidelines (CPG) Guidelines for the diagnosis and treatment of pulmonary hypertension: the Task Force for the Diagnosis and Treatment of Pulmonary Hypertension of the European Society of Cardiology (ESC) and the European Respiratory Society (ERS), endorsed by the International Society of Heart and Lung Transplantation (ISHLT). Eur Heart J. 2009; 30: 2493-2537. 